\title{
EGFR NP_005219.2:p.P772_H773insQV
}

National Cancer Institute

\section{Source}

National Cancer Institute. EGFR NP 005219.2:p.P772 H773insQV. NCI Thesaurus. Code C98679.

An insertion of the amino acid sequence glutamine-valine between the proline at position

772 and the histidine at position 773 of the epidermal growth factor receptor protein. 